\title{
VEGF-C and COX-2 expression in papillary thyroid cancer
}

\author{
Päivi Siironen, Ari Ristimäki ${ }^{1,2}$, Kirsi Narko ${ }^{2}$, Stig Nordling ${ }^{1}$, Johanna Louhimo, \\ Sture Andersson ${ }^{3}$, Reijo Haapiainen and Caj Haglund
}

\footnotetext{
Department of Surgery, Helsinki University Central Hospital, P O Box 340, FIN-00029 HUCH, Helsinki, Finland

${ }^{1}$ Department of Pathology, University of Helsinki and Helsinki University Central Hospital, Helsinki, Finland

${ }^{2}$ Molecular and Cancer Biology Program, Biomedicum Helsinki, University of Helsinki, Helsinki, Finland

${ }^{3}$ Hospital for Children and Adolescents, University of Helsinki, Helsinki, Finland
}

(Requests for offprints should be addressed to C Haglund; Email: caj.haglund@ @us.fi)

\begin{abstract}
In papillary thyroid cancer (PTC), age appears to be the most important single prognostic factor. Another characteristic feature is the lack of association between survival and lymph node metastases. Earlier, we found that expression of cyclooxygenase-2 (COX-2) is higher in older PTC patients, in agreement with the finding that older patients have a worse prognosis. Recent findings suggest that COX-2 can up-regulate vascular endothelial growth factor-C (VEGF-C) expression. Here, we investigated whether expression of VEGF-C differs between young and older PTC patients and whether expression of VEGF-C and COX-2 are correlated. Our retrospective study comprised 106 PTC patients selected by age: those under 35 or over 55 at diagnosis. Paraffin-embedded tissue samples were analysed by immunohistochemistry for VEGF-C protein expression. Furthermore, we investigated by quantitative RT-PCR and enzyme immunoassay the relationship between VEGF-C and COX-2 expression in papillary thyroid cancer cells (NPA cells). VEGF-C expression was significantly increased with age. In the tumours from older lymph node-positive (N1) patients, VEGF-C expression was significantly higher than in the tumours from young N1 patients. Moreover, all patients who died of cancer or who developed distant metastases were old, and most tumours from these patients (4 of 5 ) expressed VEGF-C and had had nodal metastases at the time of primary operation. Immunohistochemically, expression of COX-2 and VEGF-C correlated strongly. In cell culture, this correlation was not so clear, because the COX-2 selective inhibitor, NS-398, did not reduce VEGF-C expression. However, as both COX-2 and VEGF-C were induced by the tumour promoter phorbol 12-myristate 13-acetate (PMA), the same factors may control them both.
\end{abstract}

Endocrine-Related Cancer (2006) 13 465-473

\section{Introduction}

Papillary thyroid cancer (PTC) is a unique cancer for two reasons; first, its prognosis depends largely on age, and secondly, lymph node metastases (LNM) do not necessarily indicate poor survival. Many authors have reported that lymph node metastases are associated with an increased rate of locoregional recurrence of disease but not with survival (Simpson et al. 1987, DeGroot et al. 1990, McHenry et al. 1991, Lin et al. 1999, Beasley et al. 2002). Some authors have, however, shown that in older patients, LNM have an adverse effect on survival
(Harwood et al. 1978, Mazzaferri \& Jhiang 1994, Passler et al. 2004). LNM, common in PTC, are more frequent among young patients whose prognosis is excellent. Such good prognosis in young patients could be explained by the hypothesis that these patients have a unique genetic pattern permitting adherence and retention of cells in regional lymph nodes that is unrelated to their capacity to grow in other organs (Cady 1998). In agreement with this hypothesis, lymph node metastases have been associated with poor prognosis only in older PTC patients (Harwood et al. 1978, Tubiana et al. 1985, Mazzaferri \& Jhiang 1994). 
We previously reported that cyclooxygenase- 2 (COX-2) expression is higher in the tumours from older PTC patients and that this could explain the more aggressive behaviour of PTC in the older age group (Siironen et al. 2004). COX-2 is involved in the formation of prostanoids from arachidonic acid and, in normal tissues, it is induced in response to a wide range of cellular signals. Higher COX-2 expression correlates with a poor clinical outcome in various cancers (Sheehan et al. 1999, Salmenkivi et al. 2001, Buskens et al. 2002, Denkert et al. 2002, Ristimäki et al. 2002), and selective inhibition of COX-2 suppresses tumour growth (Molina et al. 1999, Grossman et al. 2000, Higashi et al. 2000, Souza et al. 2000). Moreover, COX-2 expression is associated with lymph node metastasis (Ryu et al. 2000, Costa et al. 2002).

Recently, a novel correlation of COX-2 with vascular endothelial growth factor-C (VEGF-C) was reported in human lung adenocarcinoma, and COX-2 was found to up-regulate VEGF-C expression ( $\mathrm{Su}$ et al. 2004). Later, correlation of VEGF-C with COX-2 was also demonstrated in head and neck squamous cell carcinoma and in oesophageal squamous cell carcinoma (Byeon et al. 2004, Kyzas et al. 2004). VEGF-C, originally found in the human prostatic adenocarcinoma cell line (Joukov et al. 1996), stimulates lymphatic proliferation and is expressed in cancers metastasizing to lymph nodes (Jeltsch et al. 1997, Mandriota et al. 2001). Papillary thyroid cancer also expresses VEGF-C (Bunone et al. 1999, Fellmer et al. 1999, Shushanov et al. 2000, Tanaka et al. 2002a,b, Hung et al. 2003). Some of these studies have also demonstrated correlations between lymph node metastasis and high VEGF-C levels (Bunone et al. 1999, Tanaka et al. $2002 a, b)$, but no correlations with other clinical parameters. To the best of our knowledge, the relationship between age at diagnosis and VEGF-C expression in PTC has not been reported previously.

To address the issue of age and LNM in PTC, we compared the expression of VEGF-C in young and older PTC patients. Due to the hypothesis of differently behaving lymph node metastases in young and older PTC patients (Cady 1998), we hypothesized that the lymphangiogenic factor VEGF-C is expressed differently in these two age groups. Supporting this idea is our earlier finding of higher COX-2 expression in tumours from older patients (Siironen et al. 2005). As others have demonstrated COX-2-mediated VEGF-C upregulation (Byeon et al. 2004, Kyzas et al. 2004, Su et al. 2004), we immunohistochemically examined
VEGF-C expression in PTC, comparing it with the expression of $\mathrm{COX}-2$, and studied the relationship of VEGF-C and COX-2 expression in a papillary thyroid cancer cell line (NPA). Phorbol 12-myristate 13-acetate (PMA) is a well-known inducer of COX-2 in several cell types and is also known to induce VEGF-C. Previously, we have also shown that PMA stimulates both COX-2 and VEGF-C expression (Enholm et al. 1997, van Rees et al. 2003). To block PMA-induced prostanoid production, we used the COX-2 selective inhibitor, NS-398, to see if VEGF-C expression is dependent on COX-2.

\section{Materials and methods}

\section{Patients}

During a 10-year period (1987 through 1996), 259 consecutive patients with papillary thyroid cancer were treated at the Department of Surgery of Helsinki University Central Hospital (HUCH). For comparison of young versus old patients, those younger than 35 years and those older than 55 years at diagnosis (cut-off age of tumour-nodemetastasis (TNM) classification \pm 10 years) (Sobin $\&$ Wittekind 1997) were selected $(n=128)$ and their clinical data were retrospectively reviewed. Appropriate clinical information and follow-up data were available on $108(84 \%)$ of these patients. Two patients were excluded; one had histology of tall cell variant and anaplastic carcinoma, and the other had cystic small papillary carcinoma. Therefore, 106 patients were included in this study. Papillary thyroid carcinomas were staged according to the TNM classification of 1997 (Sobin \& Wittekind 1997).

Most of these patients underwent total thyroidectomy (98 of 106), and all patients having a positive postoperative whole body scan received radioactive iodine (93 of 98). The eight patients who underwent lobectomy had microcarcinoma.

Histologically, of the 106 tumours, 103 (97\%) were of the usual type, two were the diffuse sclerosing variant and one was a Hürthle cell variant (all three patients were under 35 years old). No follicular variant or tall cell variant was included in our series. The typical papillary carcinoma is referred to as the usual type. The diagnosis of PTC is based on nuclear features, which should be present in a significant proportion of the neoplasm (Vickery et al. 1985). Initial lymph node metastases (N1) were present in 26 patients $(25 \%)$, most of whom (19 of $26,73 \%$ ) were under 35 years of age. At the 
Table 1 Clinical characteristics of patients with papillary thyroid cancer aged under 35 and over 55 at diagnosis.

\begin{tabular}{|c|c|c|c|c|c|c|c|}
\hline \multirow[b]{2}{*}{ Patient characteristics } & \multicolumn{2}{|c|}{ Under 35} & \multicolumn{2}{|c|}{ Over 55} & \multicolumn{2}{|c|}{ All patients } & \multirow[b]{2}{*}{$P$-value* } \\
\hline & No. & $\%$ & No. & $\%$ & No. & $\%$ & \\
\hline No. of patients & 57 & & 49 & & 106 & & \\
\hline \multicolumn{8}{|l|}{ Extent of tumour } \\
\hline $\mathrm{T} 1(\leq 10 \mathrm{~mm})$ & 9 & 16 & 14 & 29 & 23 & 22 & NS (0.055) \\
\hline $\mathrm{T} 2(>10 \mathrm{~mm}, \leq 40 \mathrm{~mm})$ & 37 & 65 & 24 & 49 & 61 & 57 & \\
\hline Т3 $(>40 \mathrm{~mm})$ & 6 & 10 & 1 & 2 & 7 & 7 & \\
\hline T4 (beyond the capsule) & 5 & 9 & 10 & 20 & 15 & 14 & \\
\hline \multicolumn{8}{|l|}{ Lymph node metastases } \\
\hline Absent & 38 & 67 & 42 & 86 & 80 & 75 & 0.019 \\
\hline Present & 19 & 33 & 7 & 14 & 26 & 25 & \\
\hline \multicolumn{8}{|l|}{ Distant metastases } \\
\hline Absent & 57 & 100 & 49 & 100 & 106 & 100 & \\
\hline Present & 0 & 0 & 0 & 0 & 0 & 0 & \\
\hline \multicolumn{8}{|l|}{ TNM stage $\dagger$} \\
\hline I & 57 & 100 & 14 & 29 & 71 & 67 & $<0.001$ \\
\hline II & 0 & 0 & 22 & 45 & 22 & 21 & \\
\hline III & 0 & 0 & 13 & 26 & 13 & 12 & \\
\hline IV & 0 & 0 & 0 & 0 & 0 & 0 & \\
\hline \multicolumn{8}{|l|}{ Size $(\mathrm{cm})$} \\
\hline$<1$ & 9 & 16 & 14 & 29 & 23 & 22 & NS (0.617) \\
\hline $1-2$ & 27 & 47 & 18 & 37 & 45 & 43 & \\
\hline $2-4$ & 15 & 26 & 13 & 26 & 28 & 26 & \\
\hline$>4$ & 6 & 11 & 4 & 8 & 10 & 9 & \\
\hline Recurrent disease & 20 & 35 & 7 & 14 & 27 & 26 & 0.012 \\
\hline
\end{tabular}

*Analysis by Chi-square test, or by Fisher's exact test when applicable. NS, not significant.

†Tumour-node-metastases (TNM) stage according to UICC TNM classification of 1997.

time of initial surgery, no patients presented with distant metastases, but during follow-up four older patients (aged 61 to 81 years) developed distant metastases (pulmonary 2, mediastinal 1, pulmonary and skeletal 1). Median follow-up in young patients was 10.1 years (range 5.1-15 years) and in older patients it was 9.2 years (range 5.1-14.3 years). Tumours recurred in 27 patients $(25 \%)$, defined as evidence of disease (local or distant) appearing more than 6 months after the primary operation. Death was related to PTC in 3 of the 106 patients (3\%), all of whom were old (range 61-81 years) and had primary LNM. The patients' clinical characteristics are shown in Table 1. Clinical staging was based on the TNM classification of the International Union Against Cancer (Sobin \& Wittekind 1997).

\section{Immunohistochemistry}

Formalin-fixed, paraffin-embedded archival tissue blocks of the 106 tumour samples were freshly cut into $4-\mu \mathrm{m}$ sections onto slides and dried to fix for 12 to $24 \mathrm{~h}$ at $37^{\circ} \mathrm{C}$. Freshly cut sections were deparaffinized in xylene and rehydrated through graded alcohol and deionized water. Then sections were heated in a microwave oven in $0.3 \%$ citrate buffer $(\mathrm{pH} 6.0)$ for $4 \times 5 \mathrm{~min}$, and washed with phosphate-buffered saline (PBS) for $2 \times 5 \mathrm{~min}$. Endogenous peroxidase activity of the tissues was blocked by 30-min incubation in methanol containing $1.6 \%$ hydrogen peroxide followed by a PBS wash for $3 \times 5 \mathrm{~min}$. Afterwards, the sections were treated with normal horse serum for $15 \mathrm{~min}$. A rabbit polyclonal antibody against human VEGFC (Zymed Laboratories, Inc., South San Francisco, CA, USA) was then applied at a dilution of $1: 500$ overnight.

After this overnight incubation, the sections were first reacted for $30 \mathrm{~min}$ with biotinylated anti-mouse IgG diluted in PBS containing $1 \%$ normal horse serum or with anti-rabbit IgG diluted in PBS containing $1 \%$ normal goat serum, and then for $30 \mathrm{~min}$ in avidin-biotinylated peroxidase complex (Vectastain ABC kits, Vector Laboratories, Inc., Burlingame, CA, USA). Between all steps in the 
staining procedure, sections were washed three times with PBS for $5 \mathrm{~min}$. Staining was visualized with 3-amino-9-ethyl-carbazole (A5754; Sigma, St Louis, MO, USA), $0.2 \mathrm{mg} / \mathrm{ml}$ in $0.5 \mathrm{M}$ acetate buffer containing $0.03 \%$ hydrogen peroxide (pH 5.0) for $15 \mathrm{~min}$. Subsequently, the sections were washed thoroughly in tap water. Meyer's haematoxylin served as a counterstain. Finally, the sections were mounted in an aqueous mounting medium (Aquamount; BDH, Poole, Dorset, UK).

Specimens of breast cancer served as positive controls. As the negative control we used PBS instead of the primary antibody.

Scoring of VEGF-C was performed by an experienced pathologist $(\mathrm{S} \mathrm{N})$ and by an investigator (P S) without knowledge of the clinical data. Cytoplasmic immunoreactivity for VEGF-C was evaluated according to the extent of staining, with staining intensities scored as: 0 , no cells stained; 1 , less than $10 \%$ of cells stained; $2,11 \%$ to $50 \%$ of cells stained; 3 , more than $50 \%$ of cells stained. For statistical analysis, we grouped patients into two groups, positive expression being defined by staining of more than $10 \%$ of the tumour area (scores $2-3$ ).

\section{Statistical analysis}

Correlation of VEGF-C with clinical variables (age, gender, stage, tumour size, and recurrent disease) was assessed with the Chi-square test or with Fisher's exact test when applicable. Data were evaluated in three categories separately: young, old, and all patients. VEGF-C expression was also compared with that of COX-2 in the same specimens (Siironen et al. 2004). A $P$-value less than 0.05 was regarded as statistically significant.

\section{Cell culture}

Human papillary thyroid carcinoma cells (NPA) were grown in RPMI supplemented with $10 \%$ fetal calf serum (Promo Cell, Heidelberg, Germany), $2 \mathrm{mM}$ L-glutamine, and antibiotics (BioWhittager, Verviers, Belgium). Cells were incubated with PMA $\quad(10 \mathrm{ng} / \mathrm{ml} ; \quad$ Sigma $), \quad \mathrm{NS}-398 \quad(5-10 \mu \mathrm{M}$; Cayman Chemical Co, Ann Arbor, MI, USA), or arachidonic acid $(10 \mu \mathrm{M}$; Sigma) for the time periods indicated.

\section{Prostaglandin $E_{2}\left(P G E_{2}\right)$ and VEGF-C enzyme immunoassay (EIA)}

$\mathrm{PGE}_{2}$ levels were measured in cell culture medium by an EIA from Cayman Chemical Co., and
VEGF-C levels were measured by an EIA from Zymed Laboratories according to the manufacturers' instructions.

\section{Real-time quantitative RT-PCR}

Total RNA from NPA cells was isolated using Trizol Reagents (Invitrogen, Carlsbad, CA, USA), and RNA $(1 \mu \mathrm{g})$ was converted to cDNA with Moloney murine leukaemia virus reverse transcriptase (Promega, Madison, WI, USA), RNasin (Promega), 2'-deoxynucleoside 5'-triphosphates (Amersham Pharmacia Biotech Inc, Bucks, UK), and random primers (Invitrogen). COX-2 and VEGF-C mRNA expression was quantified by TaqMan real-time RT-PCR and the Gene Amp 5700 Sequence Detection System (Applied Biosystems, Foster City, CA, USA). VEGF-C primers and TaqMan probe sequences were those used by Hung et al. (2003) and were purchased from Sigma. Human TATA-binding protein (TBP) served as an endogenous control to normalize expression of VEGF-C and COX-2 mRNA levels. COX-2 and TBP Assays-on-Demand came from Applied Biosystems. Each reaction was run in triplicate, with relative quantitation performed by the comparative $\mathrm{Ct}$ method (Applied Biosystems User Bulletin \#2).

\section{Results}

\section{VEGF-C immunohistochemistry}

Tumours from older patients were more often judged to have positive VEGF-C staining $(P<0.001)$ compared with the younger group. Among all 106 tumours, positive VEGF-C expression was evident in $40(37.7 \%)$ : in 12 out of 57 $(21.1 \%)$ in younger patients and in 28 out of 49 $(57.1 \%)$ in older patients.

Lymph node metastases were present in 26 patients, and VEGF-C expression was positive in 8 of these tumours. VEGF-C immunoreactivity appeared in 2 of 19 younger and in 6 of 7 older patients, i.e. most of the older node-positive patients were VEGF-C-positive, and conversely, most of the young N1 patients were VEGF-Cnegative $(P=0.001)$ (Table 2$)$.

Of the 106 patients, we classified five patients as being high-risk. These patients either died of cancer or developed distant metastases during follow-up. All five high-risk patients were old. In four patients the tumours expressed VEGF-C (Table 3). 
Table 2 VEGF-C expression in patients under 35 and over 55 by nodal status.

\begin{tabular}{llcc}
\hline Age group & $\begin{array}{c}\text { Nodal } \\
\text { metastases }\end{array}$ & $\begin{array}{c}\text { VEGF-C- } \\
\text { positive }(\boldsymbol{n})\end{array}$ & $\begin{array}{c}\text { VEGF-C- } \\
\text { negative }(\boldsymbol{n})\end{array}$ \\
\hline Under 35 $(n=57)$ & N0 & 10 & 28 \\
& N1 & 2 & 17 \\
Over 55 $(n=49)$ & N0 & 22 & 20 \\
& N1 & 6 & 1 \\
\hline
\end{tabular}

${ }^{*}$ Nodal metastases: N0, absent; N1, present.

Patients with LNM showed significant differences in VEGF-C expression between age groups $(P=0.001)$. Those without LNM also showed significant differences between age groups $(P=0.017)$.

VEGF-C expression correlated strongly with the expression of COX-2 when all patients were analysed together $(P<0.001)$ (Table 4$)$. In the young patient group, this correlation was not significant $(P=0.120)$ but it was significant in the old patient group $(P=0.006)$.

\section{Cell culture}

We showed that NPA cells expressed VEGF-C and COX-2 mRNA and that their expression was induced by PMA (Fig. 1). As a measure of the expression of COX-2 at the protein level, enzyme activity was analysed by measuring $\mathrm{PGE}_{2}$ production after arachidonic acid incubation. PMA induced production of $\mathrm{PGE}_{2}$, and the COX-2 selective inhibitor, NS-398, blocked both basal and PMA-induced $\mathrm{PGE}_{2}$ synthesis (Fig. 2). To study whether COX-2-derived prostanoids are responsible for VEGF-C expression in NPA cells, we treated the cells with PMA and NS-398 and measured VEGF-C protein expression by EIA. PMA caused a 2.7 -fold increase in VEGF-C protein production after $24 \mathrm{~h}$ incubation. NS-398 failed, however, to reduce the basal or PMA-induced VEGF-C expression (Fig. 3).
Table 4 Correlation between VEGF-C and COX-2 immunohistochemical expression in papillary thyroid cancer.

\begin{tabular}{lllll}
\hline & & \multicolumn{2}{c}{ COX-2 } & \\
\cline { 3 - 4 } VEGF-C & No. (\%) & Low (\%) & High (\%) & P-value* \\
\hline Low & $66(62.3)$ & $52(76.5)$ & $14(36.8)$ & $<0.001$ \\
High & $40(37.8)$ & $16(23.5)$ & $24(63.2)$ & \\
\hline
\end{tabular}

*Statistical analysis by Chi-square test, or by Fisher's exact test when applicable.

\section{Discussion}

In our series of 106 PTC patients, VEGF-C expression was significantly increased with age and, interestingly, most tumours from older $\mathrm{N} 1$ patients expressed VEGF-C whereas tumours from younger N1 patients did not $(P=0.001)$. All patients who died of cancer or who developed distant metastases were old, and most tumours from these patients expressed VEGF-C and had had nodal metastases at the time of primary operation.

As age is the most important prognostic factor in PTC, our aim was to compare younger and older PTC patients. In the classification systems for PTC, the cut-off age lies between 40 and 70 years (AGES, 40; AMES, 41 in men, 51 in women; MACIS, 40; SAG, 70; TNM, 45) (Hay et al. 1987, Cady \& Rossi 1988, Akslen 1993, Hay et al. 1993, Sobin \& Wittekind 1997). Since all these ages are estimates, we assumed that results would be more reliable when comparing patients under 35 with those over 55 years (45 years according to TNM \pm 10 years).

PTC is the only human cancer that shows no clear-cut relationship between lymph node metastases and survival (Bacourt et al. 1986, DeGroot et al. 1990, Samaan et al. 1992). Some studies have, however, shown that LNM also correlate with death in PTC, especially in older patients

Table 3 Characteristics of five patients out of 106 classified as high risk (with distant metastases or dying from papillary thyroid cancer).

\begin{tabular}{lcccccc}
\hline $\begin{array}{l}\text { Patient } \\
\text { number }\end{array}$ & $\begin{array}{c}\text { TNM classification } \\
\text { at diagnosis* }\end{array}$ & $\begin{array}{c}\text { Age } \\
\text { (years) }\end{array}$ & Sex & & $\begin{array}{c}\text { Distant metastases } \\
\text { during follow-up }\end{array}$ & $\begin{array}{c}\text { Death } \\
\text { from PTC } \\
\text { expression }\end{array}$ \\
\hline 1 & T2N1M0 & 61 & Female & + & lung, bone & + \\
2 & T4N1M0 & 81 & Female & + & mediastinium & + \\
3 & T4N1M0 & 78 & Female & - & - & + \\
4 & T4N1M0 & 62 & Male & + & lung & + \\
5 & T2N0M0 & 80 & Female & + & lung & + \\
\hline
\end{tabular}

${ }^{*} \mathrm{~T}=$ extent of tumour: T1 $(\leq 10 \mathrm{~mm}), \mathrm{T} 2(>10 \mathrm{~mm}, \leq 40 \mathrm{~mm}), \mathrm{T} 3(>40 \mathrm{~mm}), \mathrm{T} 4$ (beyond thyroid capsule); $\mathrm{N}=$ nodal metastases: N0 absent, $\mathrm{N} 1$ present; $\mathrm{M}=$ distant metastases: $\mathrm{M} 0$ absent, $\mathrm{M} 1$ present. 


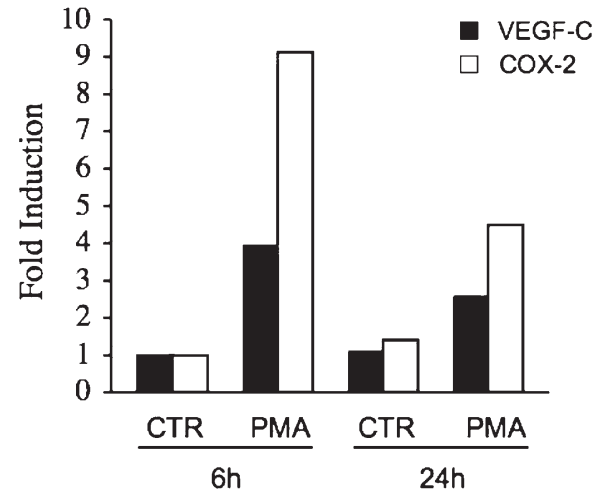

Figure 1 PMA induces VEGF-C and COX-2 mRNA expression in thyroid papillary carcinoma cells. Cells were treated with phorbol 12-myristate 13-acetate (PMA) $(10 \mathrm{ng} / \mathrm{ml})$ for $6 \mathrm{~h}$ and $24 \mathrm{~h}$. The expression of VEGF-C and COX-2 mRNA was measured by TaqMan RT-PCR. Data are shown as fold induction of the 6-h control (CTR) samples. This experiment was repeated twice with similar results.

(Harwood et al. 1978, Tubiana et al. 1985, Mazzaferri \& Jhiang 1994). Our results agree with these studies. Four older patients developed distant metastases, and three of these also had nodal metastases. As all three patients dying of PTC were old, with LNM, we suggest that LNM in older patients seems to be a sign of aggressive disease as it is in other cancers. Our patients' LNM were significantly more common among the younger group (33\% vs $14 \%)$, and local lymph node recurrences were also more often seen in younger patients (35\% vs $14 \%)$. Even so, none of the younger patients died of cancer or developed distant metastases. Thus, in the young, LNM did not affect survival: the cancer remains in the neck region. We therefore

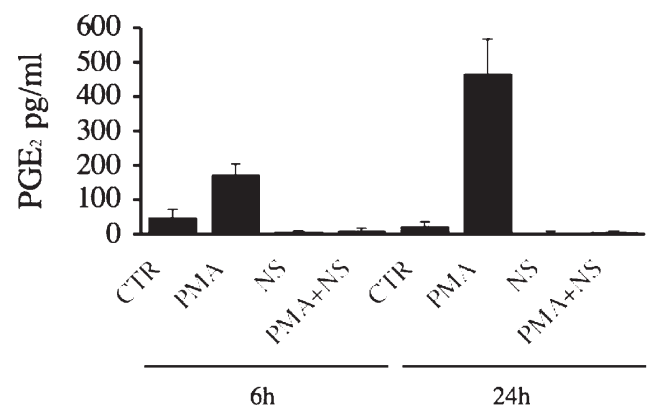

Figure $2 \mathrm{PGE}_{2}$ production in NPA cells. Cells were treated with or without the COX-2 selective inhibitor NS-398 $(5 \mu \mathrm{M})$ or PMA (10 $\mathrm{ng} / \mathrm{ml})$ or both for 6 or $24 \mathrm{~h}$, after which they were washed and incubated further with arachidonic acid $(\mathrm{AA}, 10 \mu \mathrm{M})$ for $10 \mathrm{~min}$. $\mathrm{PGE}_{2}$ levels were measured in the AA-media by enzyme immunoassay. Results are means \pm S.E.M. from four determinations. CTR, control.

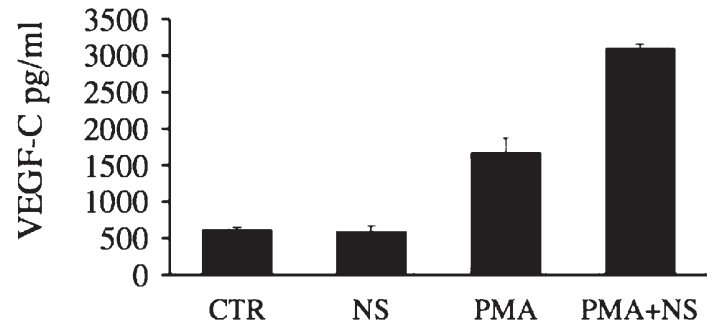

Figure 3 VEGF-C protein expression in NPA cells. Cells were treated with NS-398 $(10 \mu \mathrm{M})$ or PMA $(10 \mathrm{ng} / \mathrm{ml})$ or both for $24 \mathrm{~h}$. VEGF-C was measured in the culture medium by enzyme immunoassay. Results are means \pm S.E.M. from four determinations. CTR, control.

agree with the hypothesis of Cady (1998) that in young patients, metastatic cells in regional lymph nodes lack the capacity to grow in other organs. In our older patients the situation, however, differed, and primary LNM were correlated with poor survival.

It is notable that in our series only $25 \%$ of patients had nodal metastases (young patients $33 \%$; older patients $14 \%$ ). We do not routinely perform lymph node dissection but only remove pathological lymph nodes (so called node picking procedure). Small occult LNMs are apparently treated by routine postoperative radioiodine ablation. It is thus probable that our positive lymph nodes represent only the most aggressive metastases, those that may influence survival in contrast to micrometastases.

We found higher VEGF-C expression in tumours from older patients, a finding which could explain the more aggressive behaviour of LNMs in those PTC patients. Research has shown that VEGF-C expression in thyroid tumours is higher in patients with nodal involvement, but no correlation has been evident with other clinical parameters (Bunone et al. 1999, Tanaka et al. 2002a). In contrast, other studies demonstrated no correlation between VEGF-C expression and the occurrence of LNMs (Shushanov et al. 2000, Hung et al. 2003). We found no correlation between nodal status and VEGF-C expression when all patients were analysed together. Interestingly, a significant difference was noticeable for young and older patients analysed separately: among lymph node-positive patients, VEGF-C expression was positive in most tumours (6 of 7) from those from older patients, but only 2 of 19 tumours from the young group expressed VEGF-C. Moreover, more than half of the old N1 patients (4 of 7) either died of cancer or developed distant metastases. In older patients, 
VEGF-C up-regulation could therefore lead to increased distant dissemination of tumour cells. It could be that in older PTC patients, VEGF-C does not promote formation of lymph node metastases, but rather it induces tumour cell dissemination from lymph nodes to other organs. Supporting this hypothesis, work by Skobe et al. (2001) showed that increased VEGF-C promotes distant metastases. However, in our study, the sample size is not large enough to allow us to make a final statement on how VEGF-C induces tumour cell dissemination. Our results show a trend that VEGF-C could relate to distant dissemination of tumour cells in older patients. We need to study a larger patient series to confirm these observations.

We have reported that COX-2 expression is higher in tumours from older PTC patients (Siironen et al. 2004), and in this same patient series, immunohistochemical analysis of VEGF-C expression showed, consistent with previous results, that VEGF-C and COX-2 expression were correlated (Byeon et al. 2004, Kyzas et al. 2004). To examine any such correlation in vitro, we analysed COX-2 and VEGF-C expression in papillary carcinoma cells known to express COX-2 (Specht et al. 2002), and showed that NPA cells expressed both VEGF-C and COX-2 mRNA and that their expression was induced by PMA. Moreover, PMA induced the production of $\mathrm{PGE}_{2}$, and the COX-2 selective inhibitor, NS-398, blocked both basal and PMA-induced $\mathrm{PGE}_{2}$ synthesis, indicating that COX-2 is responsible for $\mathrm{PGE}_{2}$ synthesis both in untreated NPA cells and under stimulatory conditions. NS-398 did not, however, reduce basal or PMA-induced VEGF-C protein expression. These data suggest that both VEGF-C and COX-2 are induced by PMA in NPA cells, but VEGF-C expression is not dependent on COX-2derived prostanoids. The differences between our results and those of $\mathrm{Su}$ et al. (2004) may relate to the different cell lines studied; they studied human lung adenocarcinoma cell lines, finding that COX-2 enhanced VEGF-C gene expression through the prostanoid receptor $\left(\mathrm{EP}_{1}\right)$-dependent transactivation of the HER-2/Neu receptor. Among the four subtypes of prostanoid receptors $\left(\mathrm{EP}_{1-4}\right), \mathrm{EP}_{3}$ and $\mathrm{EP}_{4}$ are expressed in almost all tissues, whereas $\mathrm{E}_{1}$ is restricted to organs such as the kidney, lung, and gastrointestinal tract (Watabe et al. 1993, Morimoto et al. 1997); the least abundant receptor is $\mathrm{EP}_{2}$. Perhaps the difference in tissue distribution of the prostanoid receptors is one reason for these contradictory findings. Thus, because both COX-2 and VEGF-C are induced in NPA cells by PMA, the same factors may control the expression of these two markers. It would have been interesting to study several papillary thyroid cancer cell lines. We could not, however, find another papillary thyroid cancer cell line for our study.

In our study, the combination of old age, primary LNMs, and positive VEGF-C expression seems to indicate worse outcome. In older patients, but not in young ones, LNMs seem to affect survival. Based on our findings, we cannot conclude that VEGF-C is an independent indicator of aggressive disease, but higher VEGF-C in older patients could reflect the fact that in older patients, PTC is a biologically different disease.

\section{Acknowledgements}

The human papillary thyroid carcinoma cell line (NPA) was kindly provided by Professor Kid Törnqvist, Turku, Finland, who had obtained the cells from Dr Massimo Santoro, Naples, Italy. We thank Elina Laitinen, Päivi Peltokangas and Marjatta Vallas for technical assistance. This study was supported by grants from Finska Läkaresällskapet, Medicinska Understödsföreningen Liv och Hälsa, and the Helsinki University Central Hospital Research Funds. The authors declare that there is no conflict of interest that would prejudice the impartiality of this scientific work.

\section{References}

Akslen LA 1993 Prognostic importance of histologic grading in papillary thyroid carcinoma. Cancer $\mathbf{7 2}$ 2680-2685.

Bacourt F, Asselain B, Savoie JC, D’Hubert E, Massin JP, Doucet G, Leger A \& Garnier H 1986 Multifactorial study of prognostic factors in differentiated thyroid carcinoma and a re-evaluation of the importance of age. British Journal of Surgery 73 274-277.

Beasley NJ, Lee J, Eski S, Walfish P, Witterick I \& Freeman JL 2002 Impact of nodal metastases on prognosis in patients with well-differentiated thyroid cancer. Archives of Otolaryngology-Head and Neck Surgery 128 825-828.

Bunone G, Vigneri P, Mariani L, Buto S, Collini P, Pilotti S, Pierotti MA \& Bongarzone I 1999 Expression of angiogenesis stimulators and inhibitors in human thyroid tumours and correlation with clinical pathological features. American Journal of Pathology 155 1967-1976.

Buskens CJ, Van Rees BP, Sivula A, Reitsma JB, Haglund C, Bosma PJ, Offerhaus GJ, Van Lanschot JJ \& Ristimaki A 2002 Prognostic significance of elevated cyclooxygenase 2 expression in patients with adenocarcinoma of the esophagus. Gastroenterology 122 1800-1807. 
Byeon JS, Jung HY, Lee YJ, Lee D, Lee GH, Myung SJ, Yang SK, Hong WS, Kim JH, Min YI et al. 2004 Clinicopathological significance of vascular endothelial growth factor-C and cyclooxygenase-2 in esophageal squamous cell carcinoma. Journal of Gastroenterology and Hepatology 19 648-654.

Cady B 1998 Presidential address: beyond risk groups - a new look at differentiated thyroid cancer. Surgery 124 947-957.

Cady B \& Rossi R 1988 An expanded view of risk-group definition in differentiated thyroid carcinoma. Surgery 104 947-953.

Costa C, Soares R, Reis-Filho JS, Leitao D, Amendoeira I \& Schmitt FC 2002 Cyclo-oxygenase 2 expression is associated with angiogenesis and lymph node metastasis in human breast cancer. Journal of Clinical Pathology 55 429-434.

DeGroot LJ, Kaplan EL, McCormick M \& Straus FH 1990 Natural history, treatment, and course of papillary thyroid carcinoma. Journal of Clinical Endocrinology and Metabolism 71 414-424.

Denkert C, Kobel M, Pest S, Koch I, Berger S, Schwabe M, Siegert A, Reles A, Klosterhalfen B \& Hauptmann S 2002 Expression of cyclooxygenase 2 is an independent prognostic factor in human ovarian carcinoma. American Journal of Pathology 160 893-903.

Enholm B, Paavonen K, Ristimäki A, Kumar V, Gunji Y, Klefstrom J, Kivinen L, Laiho M, Olofsson B, Joukov V et al. 1997 Comparison of VEGF, VEGF-B, VEGF-C and Ang-1 mRNA regulation by serum, growth factors, oncoproteins and hypoxia. Oncogene 14 2475-2483.

Fellmer PT, Sato K, Tanaka R, Okamoto T, Kato Y, Kobayashi M, Shibuya M \& Obara T 1999 Vascular endothelial growth factor-C gene expression in papillary and follicular thyroid carcinomas. Surgery 126 1056-1061; discussion 1061-1062.

Grossman EM, Longo WE, Panesar N, Mazuski JE \& Kaminski DL 2000 The role of cyclooxygenase enzymes in the growth of human gall bladder cancer cells. Carcinogenesis 21 1403-1409.

Harwood J, Clark OH \& Dunphy JE 1978 Significance of lymph node metastasis in differentiated thyroid cancer. American Journal of Surgery 136 107-112.

Hay ID, Grant CS, Taylor WF \& McConahey WM 1987 Ipsilateral lobectomy versus bilateral lobar resection in papillary thyroid carcinoma: a retrospective analysis of surgical outcome using a novel prognostic scoring system. Surgery 102 1088-1095.

Hay ID, Bergstralh EJ, Goellner JR, Ebersold JR \& Grant CS 1993 Predicting outcome in papillary thyroid carcinoma: development of a reliable prognostic scoring system in a cohort of 1779 patients surgically treated at one institution during 1940 through 1989. Surgery 114 1050-1057.

Higashi Y, Kanekura T \& Kanzaki T 2000 Enhanced expression of cyclooxygenase (COX)-2 in human skin epidermal cancer cells: evidence for growth suppression by inhibiting COX-2 expression. International Journal of Cancer 86 667-671.
Hung CJ, Ginzinger DG, Zarnegar R, Kanauchi H, Wong MG, Kebebew E, Clark OH \& Duh QY 2003 Expression of vascular endothelial growth factor-C in benign and malignant thyroid tumours. Journal of Clinical Endocrinology and Metabolism 88 3694-3699.

Jeltsch M, Kaipainen A, Joukov V, Meng X, Lakso M, Rauvala H, Swartz M, Fukumura D, Jain RK \& Alitalo K 1997 Hyperplasia of lymphatic vessels in VEGF-C transgenic mice. Science 276 1423-1425.

Joukov V, Pajusola K, Kaipainen A, Chilov D, Lahtinen I, Kukk E, Saksela O, Kalkkinen N \& Alitalo K 1996 A novel vascular endothelial growth factor, VEGF-C, is a ligand for the Flt4 (VEGFR-3) and KDR (VEGFR-2) receptor tyrosine kinases. EMBO Journal 15 290-298.

Kyzas PA, Stefanou D \& Agnantis NJ 2005 COX-2 expression correlates with VEGF-C and lymph node metastases in patients with head and neck squamous cell carcinoma. Modern Pathology 18 153-160.

Lin JD, Chao TC, Weng HF \& Ho YS 1999 Prognostic variables of papillary thyroid carcinomas with local invasion. Endocrine Journal 46 91-98.

McHenry CR, Rosen IB \& Walfish PG 1991 Prospective management of nodal metastases in differentiated thyroid cancer. American Journal of Surgery 162 353-356.

Mandriota SJ, Jussila L, Jeltsch M, Compagni A, Baetens D, Prevo R, Banerji S, Huarte J, Montesano R, Jackson DG et al. 2001 Vascular endothelial growth factor-C-mediated lymphangiogenesis promotes tumour metastasis. EMBO Journal 20 672-682.

Mazzaferri EL \& Jhiang SM 1994 Long-term impact of initial surgical and medical therapy on papillary and follicular thyroid cancer. American Journal of Medicine 97 418-428.

Molina MA, Sitja-Arnau M, Lemoine MG, Frazier ML \& Sinicrope FA 1999 Increased cyclooxygenase-2 expression in human pancreatic carcinomas and cell lines: growth inhibition by nonsteroidal anti-inflammatory drugs. Cancer Research 59 4356-4362.

Morimoto K, Sugimoto Y, Katsuyama M, Oida H, Tsuboi K, Kishi K, Kinoshita Y, Negishi M, Chiba T, Narumiya S et al. 1997 Cellular localization of mRNAs for prostaglandin E receptor subtypes in mouse gastrointestinal tract. American Journal of Physiology 272 G681-G687.

Passler C, Scheuba C, Prager G, Kaczirek K, Kaserer K, Zettinig G \& Niederle B 2004 Prognostic factors of papillary and follicular thyroid cancer: differences in an iodine-replete endemic goiter region. Endocrine-Related Cancer 11 131-139.

van Rees BP, Sivula A, Thoren S, Yokozaki H, Jakobsson PJ, Offerhaus GJ \& Ristimaki A 2003 Expression of microsomal prostaglandin E synthase-1 in intestinal type gastric adenocarcinoma and in gastric cancer cell lines. International Journal of Cancer 107 551-556.

Ristimäki A, Sivula A, Lundin J, Lundin M, Salminen T, Haglund C, Joensuu H \& Isola J 2002 Prognostic significance of elevated cyclooxygenase-2 expression in breast cancer. Cancer Research 62 632-635. 
Ryu HS, Chang KH, Yang HW, Kim MS, Kwon HC \& Oh KS 2000 High cyclooxygenase-2 expression in stage IB cervical cancer with lymph node metastasis or parametrial invasion. Gynecology and Oncology 76 320-325.

Salmenkivi K, Haglund C, Ristimaki A, Arola J \& Heikkila P 2001 Increased expression of cyclooxygenase- 2 in malignant pheochromocytomas. Journal of Clinical Endocrinology and Metabolism 86 5615-5619.

Samaan NA, Schultz PN, Hickey RC, Goepfert H, Haynie TP, Johnston DA \& Ordonez NG 1992 The results of various modalities of treatment of well differentiated thyroid carcinomas: a retrospective review of 1599 patients. Journal of Clinical Endocrinology and Metabolism 75 714-720.

Sheehan KM, Sheahan K, O'Donoghue DP, MacSweeney F, Conroy RM, Fitzgerald DJ \& Murray FE 1999 The relationship between cyclooxygenase-2 expression and colorectal cancer. Journal of the American Medical Association 282 1254-1257.

Shushanov S, Bronstein M, Adelaide J, Jussila L, Tchipysheva T, Jacquemier J, Stavrovskaya A, Birnbaum D \& Karamysheva A 2000 VEGFc and VEGFR3 expression in human thyroid pathologies. International Journal of Cancer 86 47-52.

Siironen P, Ristimaki A, Nordling S, Louhimo J, Haapiainen R \& Haglund C 2004 Expression of COX-2 is increased with age in papillary thyroid cancer. Histopathology 44 490-497.

Siironen P, Louhimo J, Nordling S, Ristimaki A, Maenpaa H, Haapiainen R \& Haglund C 2005 Prognostic factors in papillary thyroid cancer: an evaluation of 601 consecutive patients. Tumour Biology 26 57-64.

Simpson WJ, McKinney SE, Carruthers JS, Gospodarowicz MK, Sutcliffe SB \& Panzarella T 1987 Papillary and follicular thyroid cancer. Prognostic factors in 1578 patients. American Journal of Medicine 83 479-488.

Skobe M, Hawighorst T, Jackson DG, Prevo R, Janes L, Velasco P, Riccardi L, Alitalo K, Claffey K \& Detmar M 2001 Induction of tumour lymphangiogenesis by VEGF-C promotes breast cancer metastasis. Nature Medicine 7 192-198.
Sobin L \& Wittekind C 1997 Head and neck tumours: thyroid gland. In TNM Classification of Malignant Tumours, edn 5, pp 47-50. New York: Wiley-Liss, Inc.

Souza RF, Shewmake K, Beer DG, Cryer B \& Spechler SJ 2000 Selective inhibition of cyclooxygenase-2 suppresses growth and induces apoptosis in human esophageal adenocarcinoma cells. Cancer Research 60 5767-5772.

Specht MC, Tucker ON, Hocever M, Gonzalez D, Teng L \& Fahey TJ 3rd 2002 Cyclooxygenase-2 expression in thyroid nodules. Journal of Clinical Endocrinology and Metabolism 87 358-363.

Su JL, Shih JY, Yen ML, Jeng YM, Chang CC, Hsieh CY, Wei LH, Yang PC \& Kuo ML 2004 Cyclooxygenase-2 induces EP1- and HER-2/Neu-dependent vascular endothelial growth factor-C up-regulation: a novel mechanism of lymphangiogenesis in lung adenocarcinoma. Cancer Research 64 554-564.

Tanaka K, Kurebayashi J, Sonoo H, Otsuki T, Yamamoto Y, Ohkubo S, Yamamoto S \& Shimozuma K $2002 a$ Expression of vascular endothelial growth factor family messenger RNA in diseased thyroid tissues. Surgery Today 32 761-768.

Tanaka K, Sonoo H, Kurebayashi J, Nomura T, Ohkubo S, Yamamoto Y \& Yamamoto S $2002 b$ Inhibition of infiltration and angiogenesis by thrombospondin-1 in papillary thyroid carcinoma. Clinical Cancer Research $\mathbf{8}$ 1125-1131.

Tubiana M, Schlumberger M, Rougier P, Laplanche A, Benhamou E, Gardet P, Caillou B, Travagli JP \& Parmentier C 1985 Long-term results and prognostic factors in patients with differentiated thyroid carcinoma. Cancer 55 794-804.

Vickery AL Jr, Carcangiu ML, Johannessen JV \& SobrinhoSimoes M 1985 Papillary carcinoma. Seminars in Diagnostic Pathology 2 90-100.

Watabe A, Sugimoto Y, Honda A, Irie A, Namba T, Negishi M, Ito S, Narumiya S \& Ichikawa A 1993 Cloning and expression of cDNA for a mouse EP1 subtype of prostaglandin E receptor. Journal of Biological Chemistry 268 20175-20178. 
